\title{
A magyar társadalom mentális egészségi állapotának bemutatása ${ }^{1}$
}

\section{Mental Health in the Hungarian Society}

ÖsszeFoglalás

A tanulmány célja az életminôség és az egészséggel összefüggó fogalmak meghatározása, az életminôségre hatást gyakorló tényezốk feltárása és a magyar lakosság életminôségét vizsgáló kutatások eredményeinek bemutatása. A tanulmány rámutat arra a paradoxonra, hogy miközben az életfeltételek folyamatosan javulnak a nyugati társadalmakban, a mentális panaszok egyre gyakoribbá válnak. Egyes kutatások feltárják, hogy jelenleg az európai lakosság egyharmada szenved a mentális zavarok legalább egyikében, és a magyar lakosság lelki-mentális állapota nemzetközi összehasonlításban igen kedvezótlen. A magyar népesség jelentốs részénél hiányzik a mindennapi élet kihívásaival, problémáival való lelki-szellemi megbirkózás, megküzdés képessége. E folyamatba való beavatkozás elengedhetetlen, és ebben jelentôs szerepe van és lehet a már múködô szakmai szervezeteknek és lelki segítố szolgálatoknak.
Journal of Economic Literature (JEL) kódok: I1, I3

Kulcsszavak: életminőség, egészség, mentális egészség, jóllét

\section{Summary}

The aim of the study is to define the concepts of quality of life and health, to explore the factors influencing the quality of life, and to present the results of research on the quality of life in the Hungarian population. The study highlights the paradox that as living conditions continue to improve in Western societies, mental complaints are becoming increasingly common. Some studies reveal that currently one third of the European population suffers from at least one mental disorder, and the mental status of the Hungarian population is highly unfavourable in an international comparison. The ability to cope with the challenges and problems of everyday life is absent

Dr. Tốzsér ANETT, kutatási főmunkatárs, Nemzetstratégiai Kutatóintézet (anett.tozser@nski.gov.hu). 


\section{Tudományos múhely}

in a significant part of the Hungarian population. Intervention is paramount and the existing professional organisations and psychological support services can and should have a significant role in this process.

Journal of Economic Literature (JEL) codes: I1, I3

Keywords: quality of life, health, mental health, welfare

\section{Az ÉLETMINÔSÉGGEL ÖSSZEFÜGGŐ FOGALMAK MEGHATÁROZÁSA}

Fejlódési paradoxonként írható le az a jelenség, hogy miközben a fejlett országokban az életkörülmények folyamatosan javulnak, addig az emberek mégsem érzik jól magukat, sốt egyre boldogtalanabbnak mondják magukat. Az élet területén uralkodó verseny következtében olyan „fogyasztói társadalmak” jönnek létre, amelyek az ún. „fogyasztói embertípus” kialakulásának kedveznek.

A fejlett országokban, deklarációk szintjén már az 1960-as években megjelent az életminôség javításának szükségessége. Többen Johnson elnök 1964-es elnöki kampányában, a Great Society program kapcsán tett kijelentésétôl származtatják a vizsgált fogalmat, amely szerint „céljaink elérését nem mérhetjük bankszámlák nagyságával, csak az emberek életminôségének javulásával”. Ebben az idôben tehát az anyagi szükségletek kielégítésére irányuló mennyiségi jólét (welfare) mellett elôtérbe került az immateriális dimenziókban megvalósuló jóllét (well-being) kérdésének tárgyalása is (Fekete, 2006). A fejlôdés célja tehát napjainkban, mind az USA-ban, mind Nyugat-Európában nem elsôsorban a mindenáron való gazdasági növekedés, hanem az emberek jóllétének, életminôségének javítása (Kopp-Martos, 2011). Ez azt jelenti, hogy a társadalmi fejlódés középpontjában az embernek kellene állnia, az emberi személyiségfejlődés támogatásának. Ennek ellenére azonban ma mégis az tapasztalható, hogy a társadalmat a gazdasági, fogyasztói érdekek mozgatják, és nem az ember alapvetố érdekei.

Történetileg az életminőség szót először a gazdasági növekedés fenntarthatatlanságának kritikájaként néhány kutató használta (Kovács, 2006), azonban a mai napig nincs általánosan elfogadott definíciója (Kovács, 2007). Seligman (2002) az életminôség három szintjét különíti el, amelyet a boldogsággal azonosít. A boldogság- és a boldogságkeresés három szintje a fogyasztói boldogságideál (minél több élvezet keresése), a bevonódás, flow állapot, illetve az élet értelmének keresése (Arisztotelész-féle boldogságmeghatározás). Az elsố szint a „pleasure”, a gyönyör, az élvezet szintje, a hedonikus boldogság, amely önmagában még csak az ösztönös késztetések szintjének felel meg. A modern társadalom gyakran egyedül ennek a szintnek az elérését tekinti boldogságnak (ez magyarázza a drog, az alkohol stb. átmeneti csúcsélményét). A boldogság második szintje a bevonódás, az elkötelezettség, amikor az ember teljesen feloldódik, s a legmagasabb szintú élményt éli át a feladat teljesítése közben. Ezt az optimális élményt nevezi Csíkszentmihályi flow-élménynek, áramlatnak. A boldogság harmadik szintje az értelmes élet, a valódi boldogság, ami nem élmény, nem állapot, hanem aktivitás. Ezt a szintet az önelfogadás, az életcélok, a személyes növekedés, a másokkal való pozitív kapcsolatok és az autonómia jellemzik. Ez a 
szint az elôzố szintektôl lényegesen jobb egészségi mutatókkal jár együtt (KoppMartos, 2011).

$\mathrm{Az}$ életminôség egyaránt tartalmaz objektív és szubjektív elemeket (Kovács, 2006), és az összetevői lehetnek a testi/ szomatikus faktorok (munkaképesség, funkcionális kapacitás, azaz fizikai teljesítmény), a pszichés faktorok (elégedettség, közérzet, önbecsülés, szorongás, depreszszió) és a szociális faktorok (szabadidó, családi és társadalmi kapcsolatok). Egy másik vélekedés szerint az életminôség meghatározásában fizikális, mentális, szociális és spirituális dimenziót különíthetünk el. A fizikális dimenzió olyan funkcionális paramétereket foglal magában, mint például a mozgásos aktivitással kapcsolatos mindennapi tevékenységek, az önellátás megléte, az aktivitásbeli korlátozások, a betegségspecifikus tünetek vagy a fájdalom gyakorisága. A mentális dimenzió egy belsố érzelmi-hangulati állapotot tükröz; a stressz, a szorongás, az érzelmi labilitás, a magatartáskontroll vagy a depresszió mérése a klinikai vizsgálatok részévé vált. A szociális dimenzió legfontosabb indikátora a társas integráció szintje, ezenkívül a spirituális dimenzió (a vallási közösséghez tartozás) is fontos egészségvédô faktor. A WHO életminőség-meghatározása hangsúlyozza, hogy a személyt kulturális és spirituális teljességében kell látnunk (Kopp-Pikó, 2006).

Az életminôség fogalmától elválaszthatatlan az egészség fogalma, amelyet ugyancsak nehéz objektíven meghatározni, mert összetett, többdimenziós és bonyolult lenne egy konkrét mutatóval mérni. Az Egészségügyi Világszervezet (WHO) 1946-os meghatározása szerint „az egészség a teljes testi, lelki és társadalmi jóllét, és nem egyszerúen a betegségek vagy fogyatékosságok hiánya. Az egészségnek tehát több dimenziója van, ezek a testi, a lelki egészség és a társas-szociális, társadalmi egészség" (Kopp-Martos, 2011). Az életminóség-mutatók is jól követik az egészségi állapot három fố dimenzióját, a biológiai (testi, fizikai) struktúrát, a pszichés/mentális állapotot és a szociális/társas funkcionálást.

A WHO definíciója (1946) szerint tehát az egészség egyik dimenziója a testi egészség, amely a betegségtôl mentes állapotot jelenti, és idetartozik az egészségvédô életvezetés (rendszeres testmozgás, egészséges táplálkozás, megfelelô alvás, önkárosító magatartásformák elkerülése) (Kopp-Pikó, 2006). A pszichológiai egészség az általános jóllétet, önmagunk elfogadását, az intelligenciát, a jó memóriamúködést, a világos gondolkodási képességet, az eredményes megbirkózási készségeket, a bizalom képességét, a tartalmas emberi kapcsolatokat, az intimitás képességét, a nehéz helyzetekben tapasztalható erós szociális hálót jelenti (Kopp-Pikó, 2006). A pszichológiai egészség és a mentális (lelki) egészség hasonló jelentéstartalommal bír. A legújabb WHO-meghatározás szerint a lelki (mentális) egészség a jóllét állapota, amelyben a személy megvalósítja képességeit, meg tud birkózni az élet stresszeivel, produktívan és eredményesen képes dolgozni, és hozzájárulni a közösség múködéséhez. A pszichológiai vagy lelki (mentális) egészség szorosan összefügg a társadalmi-gazdasági tényezôkkel, mint a társadalmi-gazdasági helyzet, a végzettség, az etnikai, vallási hovatartozás, a kulturális, nemi és hivatásbeli azonosságtudat (Kopp-Pikó, 2006).

Az egyén egészsége és életminôsége annak a kölcsönhatásnak a függvénye, hogy milyen módon váltja ki, illetve dol- 
gozza fel életeseményeit és életkörülményeinek változását. Az életminôséget, testi-lelki-szellemi egészséget tehát több tényezố befolyásolhatja, így például a személyes hatékonyság, amely azt a meggyózôdést jellemzi, hogy mennyire érezzük magunkat úgy, hogy kezelni tudjuk a nehéz élethelyzeteket. A kontrollvesztettség érzése a tanult tehetetlenség állapotához vezethet, amelynek egyik megjelenési formája a depressziós tünetegyüttes. A koherenciaérzés a személynek az a hite, hogy a világ értelmes, megismerhetô, befolyásolható. A személyes célok és önszabályozás arra utal, hogy a boldogság és a szubjektív jóllét állapota összefügg a megfelelô célok kitúzésével, megvalósításával. Az együttmúködés az életminôség további meghatározó tényezôje: az együttmúködó, barátságos személyiség a konstruktív társas életvezetés egyik fontos feltétele. Az ellenséges magatartás azonban - többek között - a kardiovaszkuláris megbetegedések egyik rizikófaktora. A megküzdés a mindennapi stressz, a negatív érzelmek megfelelố szabályozása, intenzitásuk csökkentésének képessége. Az aktivitás a kezdeményezó, aktív személyiség (extraverzió), a jóllét egyik fontos összetevôje (Kopp-Martos, 2011).

Napjainkban a nemzetgazdaság egy bizonyos szintjéig valóban javult az emberek jólléte, azonban a fölött már egyáltalán nem javult sem az Amerikai Egyesült Államok, sem Nyugat-Európa lakosainak elégedettsége, jólléte. Sót, az utóbbi évtizedekben a mentális panaszok a civilizált világban egyre gyakoribbá váltak, és ez az életminôség rosszabbodását eredményezi, fő́leg a társadalom viszonylag rosszabb helyzetú rétegeiben. Ezek a változások gyors pszichológiai válaszokat igényelnek, és gyakran az adaptáció nehézségeibôl eredô egyensúlyvesztés pszichológiai és élettani következményeit eredményezik. Az adaptáció zavarának jeleként kialakulhat a krónikus stressz állapota, a depreszszió vagy a tanult tehetetlenség, a vitális kimerültség, a kontrollvesztés. Ezek a jelenségek az életminôség olyan fokú romlásával járnak együtt, amelyek alapvetó szerepet játszanak a korai egészségromlásban és az idô elótti elhalálozásban.

A depresszió a "tanult tehetetlenség” modellje. Amennyiben az érzelmileg negatív helyzeteket aktivitáson keresztül kontrollálatlannak, megoldhatatlannak minôsítjük, vagy azért, mert nem ismerjük a helyes megoldást, vagy azért, mert az ehhez szükséges cselekvésre nem érezzük képesnek magunkat, szorongással reagálunk. Ha ismételten nem vagyunk képesek a negatív helyzetek megoldására, a „tanult tehetetlenség” állapota alakulhat ki, amelyet a depresszió legjobb modelljének tekintenek. Kopp Mária (2006) szerint a stressz összefügg a depresszióval. A stressz mint kihívás alapvetô a fejlôdéshez, ha folyamatosan képesek vagyunk megbirkózni a nehézségekkel. Ezért a megbirkózás („coping”) a stressz ikerfogalma. A stressz akkor válik kórossá, ha nem vagyunk képesek megbirkózni az újszerú helyzettel, és ebben az esetben a krónikus stressz, a kimerülés fázisa egyértelmúen károsító hatású. A depresszió kialakulásában a gyermekkori, családi háttér, az egyén megbirkózási képességei, szociális kompetenciája és az életesemények meghatározó szerepet játszanak. A tanult tehetetlenség lelkiállapota és élettani következményei magyarázzák, hogy a mai magyar népesség harmada szenved olyan, az életminőséget rontó tünetegyüttestôl, amely a korai halálozás szempontjából is jelentôs veszélyeztetố tényezô (Kopp, 2006). 
A tanult tehetetlenség helyett a tanult leleményesség, a tanult eróforrás-gazdagság élményét kell elsajátítani már gyermekkorban, aminek a feltétele a bizalom és az együttmúködés élménye és képessége. Ezzel összefüggésben említhetô a társadalmi tôke fogalma, amely bizalmon és együttmúködésen alapuló emberi kapcsolatok hálózatát jelenti, és amely jelentôs társadalmi erôforrás, az emberi jóllét, boldogság lényegi összetevôje. A legtöbb meghatározás a bizalmat tekinti alapvetônek a társadalmi tôke szempontjából. A bizalmatlanság azonban rosszabb lelki egészséggel jár együtt: az alacsony bizalommal rendelkezó emberek nagyobb valószínúséggel depressziósak (Kopp-Martos, 2011).

A hit és a vallási közösséghez tartozás pozitív, személyes elkötelezettségen alapuló formái ugyancsak jelentôs egészségvédó faktort jelentenek. Kiemelhetôk azok a vallási-kulturális erôforrások is, amelyek alapvetôek az egyén és a közösség megbirkózási készségeinek erôsítésében. A globális fogyasztói kultúrával szemben az Istenbe vetett hit, a vallás, a spiritualitás, a közösségiség, az egyéni léten túlmutató pozitív célok lehetôségeit kínálják (Kopp-Martos, 2011), és a rendszeres vallásgyakorlók egészséglélektani védettségét is megerôsítik (Székely-Lázár, 2013).

Ugyancsak a megküzdési mechanizmusokra tett javaslatot Kopp Mária és Skrabski Árpád (2007) tanulmánya, amely az egymástól gyakorlatilag külön fejlôdô szociológiai, pszichológiai és egészségtudományi életminôség-kutatások foobb eredményeinek összegzését végezte el, illetve mindezek ismeretében kísérletet tett a mai magyar társadalom életminóség-vizsgálatára. A szerzôk amellett ér- velnek, hogy a nemzeti azonosságtudat fontos eszköz a társadalmi anómia elkerülésére, megszüntetésére, a magyar társadalom sokszínúségének értékként való megôrzése érdekében pedig a kettôs vagy többes identitáskonstrukciókat kellene erôsíteni.

A MATERIÁlis ÉRTÉKEK HATÁSA AZ ÉLETMINÔSÉGRE

A 20. század gazdasági, ipari, anyagi fejlôdése, a fokozódó „jólét” következtében a jóllét is növekedett, és a nemzetgazdaság bizonyos szintjéig valóban javult az emberek állapota, azonban a fölött már egyáltalán nem javult sem az USA-ban, sem Európában. Az utóbbi évtizedekben az adaptáció zavaraiból eredô mentális tünetek és panaszok a civilizált világ országaiban egyre gyakoribbá váltak, és az életminôség rosszabbodását tükrözik, fôleg a társadalom viszonylag rosszabb helyzetú rétegeiben. Gregg Easterbrook több könyvében, például a The Progress Paradox (Fejlődési paradoxon) címú kötetben elemzi azt a jelenséget, hogy „miközben az életfeltételek folyamatosan javulnak a nyugati társadalmakban, az emberek jelentôs része egyre rosszabbul érzi magát” (Easterbrook, 2003). Kína fejlődésének példája is ezt mutatja: a gazdaság bôvülése mellett a boldogság csökkenése következett be, vélhetôen azért, mert a bôvülés kiélezte a társadalmon belüli különbségeket (Kopp-Martos, 2011).

Kopp Mária és Martos Tamás (2011) kutatásukban ugyancsak megállapítják, hogy az anyagi helyzet, illetve a társadalmi státusz összefüggésben van mind a testi, mind a lelki egészséggel. „A magasabb jövedelmúek, illetve a társadalmi értelemben magasabb pozíciókat betöltô sze- 
mélyek és társadalmi csoportok elégedettebbek, boldogabbnak érzik magukat, és egészségi mutatóik is jobbak”. „A státusz/ anyagi helyzet kapcsolata azonban nem lineáris: az anyagi jólét egy alacsony küszöbének elérése után a nagyobb gazdagság már alig jár együtt a jóllét, boldogság és elégedettség növekedésével.” A szerzôk azt is kimutatták, hogy társadalmi szinten nem annyira a gazdagság abszolút mértéke az elôrejelzô tényezô, hanem az egyenlőtlenség mértéke, azaz a relatív távolság (pozícióban vagy jövedelmekben) a társadalom alsó és felsố rétegei között (Kopp-Martos, 2011).

A materiális és az immateriális értékek fontosságát vizsgálta Ingelhart centrum-periféria elmélete is (1977), amely szerint egy társadalom gazdasági foka ad magyarázatot a materiális és posztmateriális értékek fontosságára. Míg állítása szerint a fejletlenebb társadalmakban a materiális értékek (pl. magas jövedelem) dominálnak, egy bizonyos fejlettségi szintet elért ország esetén a posztmateriális értékeknek (pl. egészség, család, környezetvédelem stb.) kellene túlsúlyba kerülniük. Ennek a tételnek az alkalmazhatóságát a jelenkorra cáfolni látszanak azonban azok a vizsgálati eredmények, amelyek azt mutatják, hogy például hazánkban is a materiális értékek iránti igény általában jóval elôkelőbb helyen szerepel a fontossági listán, mint a nem materiális értékek iránti (Márfi, 2007).

Az életminôség-kutatásokban megkülönböztetjük a szubjektív és az objektív oldalt. Az objektív tényezôk az életszínvonal és a környezeti körülmények objektív mérésére terjednek ki, a szubjektív tényezôk az életszínvonallal való elégedettség, elégedetlenség érzését vizsgálják. Objektív tényezôk alatt az életszínvonal és az élet- körülmények területének vizsgálatakor elsôsorban a jövedelmi helyzetet, a munkaerôpiaci státust, a fogyasztási javakkal való ellátottságot és más hasonló, materiális jellegú indikátorokat értjük, vagy a nemzetközi összehasonlításoknál az egy fốre jutó GDP-t, illetve a különbözô nemzetgazdasági mutatókból készített indexeket, mint például a központi statisztikai adatokat, kérdôíves adatbázisokat (Márfi, 2007).

Sági Matild (2000) és Andorka Rudolf (1994) vizsgálatai szerint az objektív tényezôk tekintetében Magyarországon nem túl ideális a kép: az életszínvonal relatíve magas, azonban a növekvô objektív mutatók ellenére az egészségi állapot nem javul olyan dinamikusan, mint a gazdasági helyzet. Az objektív statisztikák szerint ugyan jobban élünk, mint a volt szocialista országok zömének polgárai, de kevesebbet, rövidebb életet: a KSH adatai szerint a bruttó hazai termék volumenindexe az előzó évekhez képest 1994 óta pozitív tendenciát mutat, és az egy fơre jutó nettó nominál-átlagkereset, a reálkereset és -jövedelem is növekvô tendenciát jelez, utóbbi mutatóknál 1997 óta. Ezenkívül az is megfigyelhetô, hogy nó a fogyasztás a legtöbb fogyasztói kategória alapján. Nemcsak az élelmiszer-fogyasztás terén ment végbe jelentősebb változás, hanem a tartós fogyasztási cikkek esetében is. Objektíve a háztartások felszereltsége javul, és az életszínvonal egyre magasabb lesz, azonban ezen cikkek beszerzése csak pillanatnyi örömöt nyújt, hiányuk pedig a depriváció érzését idézik elô, illetve a növekvó jólét nem feltétlenül árulkodik javuló egészségrôl. Ezt mutatja többek között a születéskor várható élettartam is, amely pesszimista képet mutat Magyarországról. Az EU-átlagnál mind a férfiak, 
mind a nôk rövidebb életre számíthatnak (Márfi, 2007).

Az objektív mutatókhoz rendelt szubjektív mutatók esetében az derült ki, hogy a válaszadók életszínvonallal kapcsolatos elégedettségére erôs hatást gyakorol a jövedelem, valamint a lakás és a munka, amiból arra lehet következtetni, hogy az emberek többsége az életszínvonalról elsôsorban anyagi dimenzióban gondolkodik. A válaszokból az derül ki, hogy minél magasabb a megkérdezett jövedelme, annál elégedettebb az életszínvonalával. Emellett a lakás felszereltsége és értéke is hatást gyakorol a szubjektív életszínvonal megítélésére. A nem materiális tényezôk közül jelentôs hatása van az iskolai végzettségnek is az életszínvonallal való elégedettségre - hiszen hatással van a jövedelemre is -, ugyanakkor a kor, a nem és a családi állapot hatása nem szignifikáns (Márfi, 2007). A szerzók azonban azt is hangsúlyozzák, hogy a szubjektív életminôség hatása a boldogságra mindig kérdéses. Bár az életszínvonallal való elégedettségre hatással van a jövedelem, ez csak csekély mértékben befolyásolja a boldogságot. A legerôsebb kapcsolatot a boldogsággal az eddigi élettel való elégedettség mutatja. Az is látható, hogy a tágabban vett életszínvonal nagyobb hatással van a boldogságérzetre, mint a jövedelem, a lakáshelyzet és a munka. Ugyanakkor a családi élet, illetve az egészség még az életszínvonallal való elégedettségnél is fontosabb tényezô.

Kopp Mária, Székely András és Skrabski Árpád (2006a) kutatása szerint is a társadalmi-gazdasági helyzet - a nemzetközi mutatókkal összhangban - a magyar népesség életminôségének is alapvetô meghatározója. A magasabb társadalmi-gazdasági helyzetú rétegekben még 65 éves kor felett sem romlik alapvetôen az élet minôsége, ugyanakkor a legalsó társadalmi-gazdasági helyzetú rétegekben már 45 év alatt is igen súlyos az életminóség-romlás. A gazdasági ágazatok közül, a férfiak között az egészségügyben, az oktatás-kultúra és a pénzügyekben dolgozók számoltak be a legpozitívabb életminôségrôl, míg a nốk között az oktatás-kultúra területén dolgozók. A férfiak esetében a tanulók, a vállalkozók, a közalkalmazottak és az alkalmazottak depresszióértékei lényegesen jobbak az átlagosnál (legalább 30\%-kal alacsonyabbak), a nók esetében ugyanezeket a csoportokat, valamint a gyesen, gyeden lévôket jellemzi az átlagosnál legalább 30\%-kal alacsonyabb depressziópontszám. A férfiak közül kiugróan leginkább az egészségügyben dolgozók, míg a nốk esetében az oktatás-kultúra területén dolgozók érzik úgy, hogy az életnek van értelme, legkevésbé mindkét nemben a gazdasági területen dolgozók.

A GDP és az életminôség legfontosabb trendjeit Magyarországon az 1990 és 2010 közötti időszakban Kopp Mária vezetésével vizsgálták (Kopp-Martos, 2011). A szerzók megállapították, hogy a GDP az 1990-es évek eleji mélyponthoz képest folyamatosan nôtt 2009-ig, amikor a világgazdasági recesszió következtében visszaesett. A szubjektív egészség alakulásáról elmondható, hogy mind a férfiak, mind pedig a nôk esetében növekvő tendenciát mutat, azaz egyre nagyobb azok aránya a felnôtt népességen belül, akik egészségi állapotukat összességében jónak minôsítik. A boldogságszintrôl is megállapítható, hogy egybeesik a GDP növekedésével, azonban 2006-ban annak ellenére figyelhető meg egy jelentôs visszaesés, hogy a GDP-ben ez a tendencia nem látható. Az általánosságban vett bizalom is jelentôs 
változáson ment keresztül az elmúlt húsz évben, és ez a változás éppen ellentétes irányú, mint a gazdasági fejlôdés tendenciája. Az adatok arra utalnak, hogy a magyar társadalomban az emberekbe vetett bizalom mértéke a rendszerváltás óta folyamatosan csökken. A depresszivitás mértéke a bizalommal ellentétben kevert mintázatot mutat: a GDP növekedésével együtt visszaesett, majd növekedésnek indult: 1988-ban még csak a felnótt népesség 2,7\%-a panaszkodott súlyos, kezelésre szoruló depressziós tünetegyüttesrốl. Ez az arány 1995-ben már 7,1\%-ra emelkedett, és ugyanezt az arányt találták a 2002es felmérés során is, miközben összességében csökkent a depresszivitás mértéke. 2005-2006-ban a súlyos depressziós tünetekrốl beszámolók aránya tovább nôtt, 11,2\%-ra. A szerzók megállapítják, hogy a magyarok általában depressziósabbak, mint más országok népei, azonban a leszakadó rétegekben, az állandó krónikus stressz, bizonytalanság állapotában élók között nagyon magas a negatív hangulati állapot és az ezzel együtt járó negatív életminôség.

\section{A MAgYAR NÉPESSÉG LELKIÁLLAPOTÁT VIZSGÁLÓ KUTATÁSOK EREDMÉNYEI}

A WHO szerint a 2000 utáni évtizedekben az egészségügy legsúlyosabb problémái a lelki betegségek, ezen belül is a depresszió és annak következményei lesznek. A mentális megbetegedések Európa egyik legnagyobb kihívását jelentik. Az európai lakosságnak több mint egyharmada szenved a mentális zavarok legalább egyikében (WHO, 2013; ÁSZ, 2012). A mentális zavarok, beleértve a depressziót, a szorongást és skizofréniát, számos európai országban - beleértve
Magyarországot is - a fogyatékosság és a korai nyugdíjba vonulás fố okait jelentik (WHO, 2013).

Magyarország számára a mentális és lelki egészség, megújulás, megerôsödés és gyarapodás ügye nemzeti sorskérdés, határon innen és túl. Az Egészséges Nemzetért Népegészségügyi Program (20012010) és a Semmelweis-terv (2011) alapvetố megállapítása, hogy a magyar lakosság lelki-mentális állapota nemzetközi összehasonlításban igen kedvezôtlen, jelentősen elmarad az ország gazdasági helyzete alapján várhatótól. A népesség jelentôs részénél hiányzik a mindennapi élet kihívásaival, problémáival való lelki-szellemi megbirkózás, megküzdés (coping) képessége, és alacsony szintú a lelki ellenállás (reziliencia) képessége is. A lelki értékek elhanyagolása jellemzó, széleskörúen elterjedtek a lelki-spirituális természetú problémák, a pszichés és mentálhigiénés zavarok. Olyan mértékú és tempójú a mindennapi élet és az értékek átrendezôdése, hogy a sodrás szabta irány kontrollálásához nagyfokú tudatosságra és szervezettségre van szükségünk. Látnunk kell a tényeket, és aktív szerepet, felelôsséget kell vállalnunk az egyén és a közösség testi, lelki, mentális/szellemi és szociális egészségének fejlesztésében, helyreállításában.

A magyar lakosság testi és lelki állapotát, ennek pszichológiai és szociológiai háttértényezóit Juhász Pál kutatásainak folytatásaként Kopp Mária és Skrabski Árpád vezetésével 1983-ban, 1988-ban, 1994-1995-ben országos reprezentatív felmérések vizsgálták. A Hungarostudy 2002 és 2005/2006 a fent említett kutatások folytatása volt (Rózsa et al., 2006; Kopp-Skrabski-Székely, 2006b). A vizsgálatok számot adtak a magyar népesség 
egészségi állapotának alakulásáról, lehetôvé téve a népegészségügyi szempontból legjelentôsebb egészségproblémák és legfőbb befolyásoló tényezôik rendszeres monitorozását.

A vizsgálatba bevont pszichológiai életminôség-mutatók a WHO Jóllét Index, a Beck Depresszió Kérdôív, a reménytelenségskála, a szorongás-, a vitáliskimerültség-, a kompetencia- és az „élet értelme” koherenciamutató. Az egészséggel kapcsolatos életminôség-mutatók: az egészségi állapot önbecslése, a munkaképesség-csökkenés, a fájdalmakkal kapcsolatos korlátozottság, a munkaképtelen napok önbecslése, a betegségteher-index.

A kutatási eredmények bemutatják az anyagi helyzettel, a munkával, a lakással, a személyes kapcsolatokkal, az egészségügyi és társadalombiztosítási ellátással való elégedettség, valamint az életminóség pszichológiai és társadalmi-gazdasági háttértényezôinek nem és kor szerinti megoszlását. Külön elemezték a társadalmi-gazdasági helyzet, elsôsorban az iskolázottság, az életkor és az életminôség legfontosabb összetevôi közötti kapcsolatot.

A kérdôívek objektív és szubjektív öszszetevôket egyaránt vizsgáló kérdéscsoportokból álltak, mint a személyi adatok, a lakás és otthon, a munkahely, a háztartási adatok, a szülók adatai, az egészségre vonatkozó adatok, pszichológiai tényezôk, a stressz és életcélok, az egészségmagatartás, a vallásosság, az etnikai hovatartozás (Kopp-Skrabski-Székely 2006b).

A Semmelweis Egyetem Magatartástudományi Intézete 2013-ban folytatta a vizsgálatokat. A kérdôíves felmérés fô célja, a 18 éven felüli magyar népesség bio-pszicho-szociális helyzetének jellemzése mellett, a 18-35 éves fiatal korosztály házasodási és gyermekvállalási hajlandó- ságának felmérése, a legfontosabb tényezôk feltárása volt. A 2000 fôs lakossági minta Magyarország településhálózatát arányosan reprezentálta. A mintába kerülô személyek összetételi aránya a legfontosabb társadalmi-demográfiai mutatók szerint (nemek, életkori csoportok, iskolai végzettség, lakóhelytípus) megfelelt a teljes felnôtt népesség összetételének. A fô kérdôív kérdéscsoportjai a teljes felnôtt lakosság egészségi állapota és egészséggel kapcsolatos életminôsége jellemzőinek feltárására irányultak, valamint az ezeket befolyásoló legfontosabb háttértényezôkre (demográfiai, szociális tényezôk, az egészségmegtartás rizikó- és protektív faktorai), kiemelt szerepet szánva a családdal kapcsolatos attitúdöknek, értékeknek. A fiatalokra vonatkozó tematikus blokk azokra a kérdésekre koncentrált, amelyek mentén leírhatók a párkapcsolatok alakulásának jellemzói, a családtervezési mintázatok és gyermekvállalási stratégiák, valamint a családdal kapcsolatos attitúdök és értékek (Susánszky-Székely, 2013; Nemzeti Lelki Egészség Stratégia 2014-2020).

A 2013-ban alkalmazott kérdőív a következó skálákat tartalmazta (SusánszkySzékely, 2013): anómiaskála, aspirációs index, extrinzik célok, intrinzik célok, athéni inszomniaskála, alkoholizmust szúrô skála, a Beck-féle Depresszió Kérdôív rövidített változata. Cloninger-féle Temperamentum és Karakter Kérdôív (TCI) - önirányítottság-faktor, újdonságkeresés-faktor, kitartásfaktor. Család-munka egyensúly kérdôív, depreszszióstigma kérdőív - észlelt és személyes stigma, elégedettségskála, életcél-kérdőív rövidített változata, énhatékonyság-skála, erôfeszítés-jutalom egyensúlytalanság-kérdőív - erôfeszítés, jutalom, túlter- 
heltség, észleltstressz-skála, férfi és nôi nemiszerep-stressz kérdőív, házastársistressz-kérdőív, koherenciaérzés-skála, konfliktustaktika-skála, kötődéskérdőív - aggodalmaskodás, függôségtôl való félelem, evészavarokra vonatkozó kérdōív, WHO általánosjóllét-skála.

A hazai és nemzetközi kutatások eredményei mind megerôsítik a magyar lakosság gyenge mentális-lelki állapotát. A fóbb megállapítások a következók:

- Az egyes országok általános boldogságát vizsgáló 2013. évi World Happiness Report adatai szerint Magyarország az élettel való elégedettség tekintetében 156 ország közül a 110. helyen található. Számos, sokkal szegényebb ország is jócskán megelőz minket. Európában csupán Bulgária, Macedónia és a kaukázusi országok állnak mögöttünk (Helliwell et al., 2013).

- A 2010-es Eurobarometer-felmérés adatai szerint az európai átlaghoz képest kevesebb magyar tapasztalta az „örömet”, „boldogságot” vagy a „teljes életet”.

- Az Állami Számvevôszék 2012-ben készült jelentése szerint a „hazai lakosság mentális-lelki állapota rosszabb az európai átlagnál” (ÁSZ, 2012).

-Az Ipsos nemzetközi közvélemény-kutató által, a Reuters megbízásából, 24 országban, 18 ezer ember megkérdezésén alapuló felmérés szerint a magyar az egyik legpesszimistább nemzet (Nemzeti Lelki Egészség Stratégia 2014-2020).

- A „65 év fölötti népesség körében a befejezett öngyilkosságokat illetôen világviszonylatban a vezető helyen áll Magyarország” (Nemzeti Lelki Egészség Stratégia 2014-2020).

- A Semmelweis Egyetem Magatartástudományi Intézete által publikált Magyar Lelkiállapot 2013 címú egész- ségszociológiai tanulmánykötet szerint a „munkahelyi stresszt megélők száma 2006 óta 18-ról 29 százalékra nôtt”, és láthatóan a felsôfokú végzettség egyre kevésbé jelent garanciát ennek elkerülésére. Dr. Selye János kísérletei bizonyítják, hogy a tartós stresszbe az ember belebetegszik, majd belehal (Susánszky-Szántó, 2013).

- A Hofstede-féle vizsgálati módszerek szerint a bangladesi mutatók is jobbak a magyarokénál, melynek oka az ottani közösség összetartására vezethetô vissza; Magyarországon az 1990-es éveket követốen megnôtt az értékvesztett, anómiás állapot mértéke; tíz emberból nyolc azt mondja a felmérések szerint, hogy senki nem törôdik a másikkal, ami szintén erôs stresszfaktort jelent (Nemzeti Lelki Egészség Stratégia 2014-2020).

- A népesség jelentôs részénél hiányzik a mindennapi élet kihívásaival, problémáival szembeni lelki-szellemi megküzdési (coping) és ellenállási (reziliencia) képesség, ezzel párhuzamosan a tanult negatív attitúdök, berögzülések és az önsorsrontó gondolkodásmód generációról generációra helyezôdik át - ez, a legújabb kutatások szerint, nemcsak tanulás, hanem genetikai úton is öröklődik, illetve fölülírható.

- A gazdasági elmaradottság és a rendkívüli gyors társadalmi átalakulás miatt, Magyarország egyes megyéiben (Nógrád, Borsod-Abaúj-Zemplén) a lelki egészség mutatói jelentôs rosszabbodást mutatnak: 7-10\%-os volt a depressziós lelkiállapotú népesség arányának növekedése.

- A lelki-spirituális, pszichés-mentális, életvezetési krízis következményeként a magyarság egészében demográfiai krízis tapasztalható; a KSH adatai alapján Eu- 
rópa és a világ egyik legalacsonyabb termékenységú országa Magyarország.

- A közép-európai egészségparadoxon meghatározó tényezôje: nem önmagában a nehéz szociális helyzet, hanem a viszonylagos lemaradás szubjektív átélése erôs jellemzője a magyar társadalomnak (Kopp-Skrabski, 2007).

- Az oktatási intézményekből hiányzik a stresszel való megküzdési képesség, a relaxáció, valamint az önálló, független, probléma- és konfliktuskezeló viszonyulás és gondolkodás kialakításának módszere (Nemzeti Lelki Egészség Stratégia 2016 2020).

\section{KövetKEZTETÉSEK}

A magyarság társadalmi és gazdasági felzárkóztatása elképzelhetetlen rossz pszichés-mentális állapotú és életvezetésú dolgozó emberekkel. Éppen ezért szükségesnek látjuk a jelenlegi folyamatba való beavatkozást, mert az objektív adatok kedvezôtlen képet adnak a magyar nemzet mentális és lelki egészségérôl. Ennek legfontosabb eszköze és eleme a már múködô szakmai szervezetek és lelki segító szolgálatok szakmai támogatása néhány kiemelt, nemzetileg fontos magyar területen.

A litván uniós elnökség Mental Health: Challenges and Possibilities (Mentális egészség: kihívások és lehetôségek) címú kiemelt konferenciájának összefoglaló következtetései (EC, 2013) a WHO Mentális Egészség Akciótervével (WHO, 2013) karöltve mutattak rá a legfontosabb kormányzati teendôkre. A dokumentum alapján a kihívások területei Magyarországra is érvényesek:

- A lakosság lelki jóllétét, a mentális zavarok megelôzését és a kockázati tényezốk csökkentését elôsegítô beavatkozások nem kellóen elérhetôek, különösen a sérülékeny csoportok számára, és az interszektorális együttmúködés sem kelló mértékú. A prevencióra és lelkiegészség-promócióra az egészségügyi költségvetés túl kis hányada fordítódik. A szektorok közötti (egészségügyi, szociális, oktatási, foglalkoztatási, igazságügyi, belügyi, ifjúság és sport, innováció és kutatás, gazdasági stb.) együttmúködés nélkülözhetetlen.

- A mentális zavarban szenvedốk esélyegyenlôségének biztosítása, a szociális befogadás nehézségei, valamint az oktatás és a foglalkoztatás problémái, beleértve a fiatalok magas munkanélküliségi arányát.

- A lelki betegségek ellátásának és a kezelési rendszereinek hiányosságai: a rászorulók legalább 50\%-a semmilyen kezelést nem kap, nincsenek elérhetô szolgáltatások, valamint a meglévốk fenntartása, fejlesztése is hátrányt szenved. Különösen a gyermekek és a serdüló és ifjúsági korosztály ellátása mutat nagy hiányosságot.

- Az emberi jogok kérdései: valamenynyi EU-tagállam, így Magyarország is ratifikálta az ENSZ Fogyatékossággal élố személyek jogairól szóló egyezményét, amely szerint a visszaélés lehetóségei, a diszkrimináció kockázata a mentális problémákkal élốknél nagyobb, a szociális befogadás kisebb.

- A megfelelô számú és képzettségú szakember és gondozó (humán erôforrás) biztosítása valamennyi EU-s országban problémát jelent, amely nélkül az ellátást vagy a stratégiákat nem lehet kivitelezni.

- Jellemzố a megfelelố információk hiánya a lelki folyamatok, valamint a mentális betegségek és ellátásuk területén. Valamint kiemelten fontos e területek kutatási igénye és szükségessége. 


\section{Tudományos múhely}

\section{JEGYZETEK}

1 Jelen tanulmány bóvebb változata a Nemzetstratégiai Kutatóintézet Annales 2018 címú kiadványában jelent meg. A tanulmányban bemutatott kutatások és eredmények a Nemzetstratégiai Kutatóintézet által bonyolított EFOP-1.12.1-172017-00003 azonosító számú, „Makroregionális kutatások a Kárpát-medencében a közösségfejlesztés és társadalmi felelősségvállalás megerốsítése érdekében" projekt tevékenységeihez kötôdnek.

\section{FELHASZNÁLT IRODALOM}

ÁSZ (2012): Jelentés a pszichiátriai betegellátás átalakításának ellenôrzésérôl. 1286. sz., Állami Számvevôszék, Budapest, https://asz.hu/ storage/files/files/\%C3\%96sszes\%20jelent\%C3\%A9s/2012/1286j000.pdf?ctid=728.

EC (2013): Lithuanian Presidency conference. „Mental Health: Challenges and Possibilities" Conclusions. Vilnius, https://ec.europa.eu/ health/sites/health/files/mental_health/ docs/ev_20131010_mi_en.pdf.

Egészségügyi Minisztérium (2001): Egészséges Nemzetért Népegészségügyi Program 2001-2010. Egészségügyi Minisztérium, Budapest.

Easterbrook, Gregg (2003): The Progress Paradox. How Life Gets Better While People Feel Worse. Random House.

Fekete Zsuzsa (2006): Életminôség-koncepciók, definíciók, kutatási irányok. In: Utasi Ágnes (szerk.): A szubjektív életminőség forrásai. Biztonság és kapcsolatok. MTA Politikai Tudományok Intézete, Budapest, 277-301.

Helliwell, John - Layard, Richard - Sachs, Jeffrey (eds.) (2013): World Happiness Report 2013. UN Sustainable Development Solutions Network, New York.

Kopp Mária (2006): Az életminôség-kutatás jelentôsége a népesség jóllétének vizsgálata céljából: interdiszciplináris modell. In: Kopp Mária Kovács Mónika Erika (szerk.): A magyar népesség életminôsége az ezredfordulón. Semmelweis Kiadó, Budapest, 2-9.

Kopp Mária (szerk.) (2008): A magyar lelkiállapot. Semmelweis Kiadó, Budapest.

Kopp Mária - Martos Tamás (2011): A magyarországi gazdasági növekedés és a társadalmi jóllét, életminőség viszonya. Magyar Pszichológiai és Egészséglélektani Társaság. Jövô Nemzedékek Állampolgári Biztosa, Budapest, http://ess. tk.mta.hu/wp-content/uploads/2013/04/ kopp_gazdasagi_novekedes.pdf.

Kopp Mária - Pikó Bettina (2006): Az egészséggel kapcsolatos életminôség pszichológiai, szociológiai és kulturális dimenziói. In: Kopp Mária - Kovács Mónika Erika (szerk.): A magyar népesség életminôsége az ezredfordulón. Semmelweis Kiadó, Budapest, 10-19.

Kopp Mária - Skrabski Árpád (2007): Magyar lelkiállapot az ezredforduló után. Távlatok, www. tavlatok.hu/86/86kopp_skrabski.pdf (Letöltés: 2018. február 15.).

Kopp Mária - Skrabski Árpád - Székely András (2006a): Társadalmi-gazdasági helyzet, aktivitás és életminôség. In: Kopp Mária - Kovács Mónika Erika (szerk.): A magyar népesség életminôsége az ezredfordulón. Semmelweis Kiadó, Budapest, 273-288.

Kopp Mária - Skrabski Árpád - Székely András (2006b): Az életminôség nemi, életkor szerinti és területi jellemzối a magyar lakosság körében a Hungarostudy 2002 vizsgálat alapján. In: Kopp Mária - Kovács Mónika Erika (szerk.): A magyar népesség életminôsége az ezredfordulón. Semmelweis Kiadó, Budapest, 84-105.

Kovács Balázs (2007): Életminôség, boldogság, stratégiai tervezés. Polgári Szemle, 3. évf., 2. sz.

Kovács József (2006): Életminőség a bioetika szempontjából: elméleti problémák. In: Kopp Mária - Kovács Mónika Erika (szerk.): A magyar népesség életminôsége az ezredfordulón. Semmelweis Kiadó, Budapest, 20-24.

Márfi András (2007): A szubjektív életkörülmények társadalmi-gazdasági összefüggései. In: Utasi Ágnes (szerk.): Az életminôség feltételei. MTA Politikai Tudományok Intézete, Budapest, 6-23.

Nemzeti Erôforrás Minisztérium (2011): Semmelweis Terv 2011. Nemzeti Erôforrás Minisztérium Egészségügyért Felelôs Államtitkárság, Budapest.

Nemzeti Lelki Egészség Stratégia 2014-2020 (2014). Szakpolitikai stratégia tervezet, http://mokk. skanzen.hu/admin/data/file/20160429/ nemzeti-lelki-egeszseg-strategia.pdf.

Rózsa Sándor - Réthelyi János - Stauer Adrienne - Susánszky Éva - Mészáros Eszter - Skrabski Árpád - Kopp Mária (2006): A Hungarostudy 2002 országos reprezentatív felmérés tervezé- 


\section{Tudományos múhely}

se, statisztikai módszerei, a minta leíró jellemzôii és az alkalmazott kérdốívek. In: Kopp Mária - Kovács Mónika Erika (szerk.): A magyar népesség életminôsége az ezredfordulón. Semmelweis Kiadó, Budapest, 70-82.

Seligman, Martin (2002): Authentic Happiness. Free Press, New York.

Skrabski Árpád (2013): Társadalmi tôke és egészségi állapot az átalakuló társadalomban. Hét szabad mûvészet könyvtára, Budapest.

Susánszky Éva - Szántó Zsuzsa (szerk.) (2013): Magyar lelkiállapot 2013. Semmelweis Kiadó, Budapest.

Susánszky Éva - Székely András (2013): A Hungarostudy 2013 felmérés módszertana. In: Susánszky Éva - Szántó Zsuzsa (szerk.): Magyar lelkiállapot 2013. Semmelweis Kiadó, Budapest, 13-20.

Székely András - Lázár Imre (2013): Vallásosság és kötôdés. In: Susánszky Éva - Szántó Zsuzsa (szerk): Magyar lelkiállapot 2013. Semmelweis Kiadó, Budapest, 63-76.

WHO (2013): Mental Health Action Plan 2013-2020. World Health Organization, http:/ /apps.who. int/iris/bitstream/10665/89966/1/9789241 506021_eng.pdf (Letöltés: 2018. február 15.).

WHO (2013): The European Mental Health Action Plan. Regional Committee for Europe Sixty-third session, 16-19 September, www.euro.who.int/__data/assets / pdf_file/0004/194107/63wd11e_MentalHealth-3. pdf?ua=1 (Letöltés: 2018. február 15.). 